\title{
Translational control mechanism of HIV-1 tat1 mRNA
}

\author{
Georges Khoury*, Lilia Ayadi, Christiane Branlant \\ From Frontiers of Retrovirology 2011 \\ Amsterdam, The Netherlands. 3-5 October 2011
}

\section{Background}

The Human Immunodeficiency Virus type 1 Tat protein is a major viral transactivator which stimulates the synthesis of full length transcripts by interacting with the 5'end of all nascent viral RNAs. Translation of tat mRNAscan be cap dependent. Nevertheless, in phaseG2/M ribosomes translate tat mRNAs by an alternative initiation processdepending on anlnternal Ribosome Entry Site (IRES). This initiation is auto-stimulated by Tat [1]. Recently, SRp40 and SRp55 proteins were found to promote Gag IRES-dependent translation initiation [2]. Therefore, SR and hnRNP proteins likely play a key role in regulation of both splicing and translation of HIV-1 RNA. As we previously observed a binding of hnRNP H (3), DAZAP1 and various SR proteins in the vicinity of the tat initiation codon(4), we asked whether these proteins can regulate tat mRNA translation.

\section{Materials and methods}

To address this issue, we built mono and bicistronic constructs expressing a Tat-Renilla luciferase fusion protein or individual Tat and Renilla proteins, respectively. We used these constructs to studythe effect of an overexpression of SR and hnRNPproteins in Hela cells on the cap dependent and cap-independenttat 1 mRNA translation initiation. Efficiency of Tat production by the bi-cistronic construct was tested by measuring the Tat activity on a Firefly luciferase gene under the control of the HIV-1 LTR.

\section{Results}

Our data strongly suggest that hnRNP $\mathrm{H}$, and some of the SR proteins (ASF-SF2 and 9G8)activate the tat1 mRNA IRES, whileDAZAP1 inhibit its activity, and

AREMS, UMR 7214 CNRS-UHP, Biopôle, faculté de médecine, 54506 Vandoeuvre-lès-Nancy, France these regulationsdepends uponthe presence of the tat1 mRNA5'UTR.

\section{Conclusions}

Altogether our data reveal a complex regulation of the internal initiation of tat $1 \mathrm{mRNA}$, that may reflect the situation in human cells infected by virus HIV-1.

Published: 3 October 2011

References

1. Charnay N, Ivanyi-Nagy R, Soto-Rifo R, Ohlmann T, López-Lastra M, Darlix JL: Mechanism of HIV-1 Tat RNA translation and its activation by the Tat protein. Retrovirology 2009, 6:74.

2. Swanson CM, Sherer NM, Malim MH: SRp40 and SRp55 promote the translation of unspliced human immunodeficiency virus type 1 RNA. J Virol 2010, 84:6748-6759.

3. Jacquenet S, Méreau A, Bilodeau PS, Damier L, Stoltzfus CM, Branlant C: A second exon splicing silencer within human immunodeficiency virus type 1 tat exon 2 represses splicing of Tat mRNA and binds protein hnRNP H. J Biol Chem 2001, 44:40464-40475.

4. Ropers D, Ayadi L, Gattoni R, Jacquenet S, Damier L, Branlant C, Stévenin J: Differential effects of the SR proteins 9G8, SC35, ASF/SF2 and SRp40 on the utilization of the A1 to A5 splicing sites of HIV-1 RNA. J Biol Chem 2004, 29:29963-29973.

doi:10.1186/1742-4690-8-S2-P39

Cite this article as: Khoury et al:: Translational control mechanism of HIV-1 tat1 mRNA. Retrovirology 2011 8(Suppl 2):P39.

Submit your next manuscript to BioMed Central and take full advantage of:

- Convenient online submission

- Thorough peer review

- No space constraints or color figure charges

- Immediate publication on acceptance

- Inclusion in PubMed, CAS, Scopus and Google Scholar

- Research which is freely available for redistribution

\section{Biomed Central}

